« Memory and Maps », in : F. Daftary \& J. W. Meri, eds., Culture and Memory in Medieval Islam. Essays in honour of Wilferd Madelung. London, Tauris and The Inst. of Ismaili Studies, 2003, pp. 109-127.

\title{
Martine Gillet
}

\section{OpenEdition}

\section{Journals}

Édition électronique

URL : http://journals.openedition.org/abstractairanica/2694

DOI : 10.4000/abstractairanica.2694

ISSN : 1961-960X

Éditeur :

CNRS (UMR 7528 Mondes iraniens et indiens), Éditions de l'IFRI

Édition imprimée

Date de publication : 15 mai 2005

ISSN : 0240-8910

\section{Référence électronique}

Martine Gillet, « « Memory and Maps », in : F. Daftary \& J. W. Meri, eds., Culture and Memory in Medieval Islam. Essays in honour of Wilferd Madelung. London, Tauris and The Inst. of Ismaili Studies, 2003, pp. 109-127. », Abstracta Iranica [En ligne], Volume 26 | 2005, document 207, mis en ligne le 08 décembre 2005, consulté le 25 septembre 2020. URL : http://journals.openedition.org/ abstractairanica/2694 ; DOI : https://doi.org/10.4000/abstractairanica.2694

Ce document a été généré automatiquement le 25 septembre 2020.

Tous droits réservés 
« Memory and Maps », in : F. Daftary \& J. W. Meri, eds., Culture and Memory in Medieval Islam. Essays in honour of Wilferd Madelung. London, Tauris and The Inst. of Ismaili Studies, 2003, pp. 109-127.

\section{Martine Gillet}

Les cartes qui accompagnent les premiers textes de géographie du monde musulman ( $9^{\mathrm{e}}-10^{\mathrm{e}} \mathrm{s}$., dans la tradition d'al-BalHī) se caractérisent par des lignes droites, des angles simples, une absence de détails et des distorsions dans les distances et les directions de l'espace qui les distinguent d'une fidèle représentation de la réalité physique. L'A. les compare à la « carte » du métro de Londres et montre qu'un tel type de représentation n'était pas dû à l'ignorance. Deux reproductions de carte d'al-Istaunrī dont une représentant le Jibāl, illustrent son propos. L'A. situe ces cartes dans le genre géographique de l'époque, les compare à leurs équivalents occidentaux, et met en évidence leur utilité : non seulement tentative de mise en ordre des informations sur les pays faisant désormais partie du dār al-islām, mais aussi « aide-mémoire » car elles rendaient les données d'un itinéraire simples et mémorisables. 
INDEX

Thèmes : 4.1. Histoire médiévale

\section{AUTEURS}

MARTINE GILLET

CNRS - Paris 